\title{
Isolation and Biological Characterization of Tributyltin Degrading Bacterial from Onne Port Sediment
}

\author{
Esther Ebah, Tersagh Ichor, Gideon C. Okpokwasili \\ Department of Microbiology, University of Port Harcourt, Port Harcourt, Nigeria \\ Email: smartichor2012@gmail.com
}

Received 1 February 2016; accepted 29 February 2016; published 3 March 2016

Copyright $@ 2016$ by authors and Scientific Research Publishing Inc.

This work is licensed under the Creative Commons Attribution International License (CC BY). http://creativecommons.org/licenses/by/4.0/

(c) (i) Open Access

\section{Abstract}

Marine sediments collected from Onne Port, Rivers State Nigeria were manually polluted with tributyltin chloride (TBTCl) to evaluate the abilities of bacterial isolates to degrade the pollutant. Bacterial isolates were screened with at varying concentrations of $3 \mathrm{mM}, 5 \mathrm{mM}, 7 \mathrm{mM}$, and $10 \mathrm{mM}$. Bacterial strains with outstanding capabilities of utilizing TBTCl were biochemically and molecularly characterized. The total bacterial counts varied from $42 \times 10^{2}$ to $64.4 \times 10^{2} \mathrm{cfu} / \mathrm{g}$ when plated on MSA only and the viable counts on MSA to $3 \mathrm{mM}$ TBTCl and MSA $+5 \mathrm{mM}$ TBTCl ranged from $22 \times$ $10^{1}$ to $38.5 \times 10^{2} \mathrm{cfu} / \mathrm{g}$ and $18 \times 1^{1} \mathrm{from} 21.9 \times 10^{1} \mathrm{cfu} / \mathrm{g}$ respectively; however, the total viable count in MSA + $10 \mathrm{mM}$ TBTCl ranged from $1.1 \times 10^{1}-3.8 \times 10^{1} \mathrm{cfu} / \mathrm{g}$. Statistically, total bacterial count varied significantly across the sample sites $p<0.05$ (one-way ANOVA). The 2 isolates that showed distinctive growth in the presence of high concentration of TBTCl $(10 \mathrm{mM})$ were molecularly identified as Pseudomonas aeruginosa, and Pseudomonas fluorescens. The 16 SrRNA sequence phylogenetic analysis using BLAST program showed that the isolates were proteobacteria. Since there are scanty works on the mechanisms of the degradation of organotin, it is then important that isolates that can tolerate organotin to a large extent can be used in the cleanup of organotincontaminated site. Pseudomonas aeuroginosa and Pseudomonas fluorescens are candidates for the bioremediation of the contaminated site.

\section{Keywords}

Organotin, Tributyltin, Degradation

\section{Introduction}

Tributyltin is one of the most toxic compounds wildly used as antifouling paint applied to the hull of boats, ships,

How to cite this paper: Ebah, E., Ichor, T. and Okpokwasili, G.C. (2016) Isolation and Biological Characterization of Tributyltin Degrading Bacterial from Onne Port Sediment. Open Journal of Marine Science, 6, 193-199.

http://dx.doi.org/10.4236/ojms.2016.62015 
marine cage, fishing nets and docks and wood preservative due to its biocidal property [1] [2]. Its presence in the aquatic environment has posed serious detrimental impact on the coastal ecosystem, mainly the living biota [3] [4].

On account of increased shipping activities, erosion and transport, tributyltin compounds accumulate in harbor waters, higher organisms and sediments [5] [6]. Higher level of TBTCl has been reported in marine and fresh water harbour areas which are primarily associated with boating activity [2].

The usage of TBT and its derivative has drawn concern about the potential damage to the aquatic environment of particular significance; TBT is toxic to non-target organisms at low concentration ppt 2. It is also an endocrine disruptor which interferes with the endocrine system in organisms and humans [7]-[9]. It causes physical damage, reproductive effects, immunological effects, and imposex, and it is still uncertain if it is a carcinogen [4].

Tributyltin has been classified as a persistent organic pollutant POP but an enormous amount of this compound has already been introduced to the terrestrial and aquatic environment [1] [2]. The accumulation of TBT in environmental media and organism's tissue has become an important issue in particular as it can be biomagnified in the food chain and impacts greatly upon the highest level predator, humans.

Biodegradation is an effective process which leads to the sustainable remediation, acclimatizing microorganism under the control of suitable parameters. Biodegradation can be used to limit the level of TBT to a concentration that does not cause an impact on living organisms. Marine bacteria are known to be potent degraders of a variety of environmental pollutants [10] but little is known about the degradation of tributyltinchloride as well as the characterization of bacteria that does the degradation process, particularly in Onne Port, Nigeria which is a potential source of TBTCl contamination because of its shipping activities.

The objectives of the research were to:

- isolate bacterial capable of degrading TBTCl;

- screen isolates for their ability to utilize TBTCl;

- identify and characterize bacterial isolates resistant to TBTCl biochemically and molecularly.

\subsection{Materials and Methods}

\subsubsection{Collection of Environmental Samples}

Sediments samples were collected from 5 different sites in Onne Rivers State, Nigeria. Sediments were collected from a depth of $10 \mathrm{~m}$ from the surface with an Eckman grab (Wilelife supply Co., Nig.) into sterile polythene bags and transported immediately to the laboratory for analysis. The collected samples were used within a week for physiochemical and bacteriological analysis.

\subsubsection{Physiochemical Characterization}

The physiochemical characteristics of the sediments (Table 1) were determined in terms of pH, conductivity, nitrate, phosphate, sulphate, total organic Carbon (TOC) and potassium content following standard protocol [11].

\subsubsection{Determination of Viable Counts}

Viable counts of organotin utilizing bacteria were determined using spread plate method on mineral salt agar (MSA), containing $3 \mathrm{mM} \mathrm{TBTCl}$ according to APHA [11] while the control was plated without TBTCl. Ten fold serial dilution of samples were prepared using one gramme $(1 \mathrm{~g})$ of sediment samples in nine millimeters (9 $\mathrm{ml}$ ) of physiological saline as diluents. Dilution up to $10^{-3}$ were prepared but $10^{2}$ were spread plated on the plates in duplicates. The plates were incubated for 48 hours at room temperature of $28^{\circ} \mathrm{C}$. Viability was determined in terms of colony forming units (cfu/ml).

\subsubsection{Screening of TBTCl Resistant Bacterial Isolates}

The bacterial isolates which grew on MSA with $3.0 \mathrm{mM} \mathrm{TBTCl}$ were subcultured continuously on MSA with varying concentrations of TBTCl ranging from $5 \mathrm{mM}-10 \mathrm{mM}$. Isolates showing varying range of tolerance to TBTCl that is $5 \mathrm{mM}, 7 \mathrm{mM}$ and $10 \mathrm{mM}$ were selected for further characterization.

\subsection{Identification of TBTCl Resistant Bacterial Isolates}

\subsubsection{Biochemical Identification}

Biochemical test for tentative identification was conducted for the TBTCl resistant isolates. Biochemical tests carried out include Citrate utilization, indole production, triple sugar, iron (TSI) utilization, methyl red-voges 
proskauer, glucose, lactose, and maltose fermentation, starch hydrolysis, oxidase, motility, catalase, microscopy, and Grams reaction using standard method according to [11].

\subsubsection{Molecular Identification}

TBT resistant strains were further identified by 16 SrDNA amplification and sequencing.

\subsubsection{Polymerase Chain Reaction Analysis}

Amplification of the template DNA was performed using $2 \mathrm{ml}$ volume of the extracted DNA with Bio RAD mini thermal cycler (Mexico). The $50 \mathrm{Nm}$ PCR mixture contained $5 \mathrm{Nl}$ of deoxy nucleoside triphosphates (NDTPs) mixture (2.5 Nm) (Promega, USA), $5 \mu$ of 5 X Green GO Taq flexi butter (Promega, USA), $3.5 \mu$ of 25 $\mathrm{mm} \mathrm{MgCl}_{2}$ (Promega, USA), $2 \mu$ each of 10 pmol of both forward (primer M) and reverse (primer K) primers PA8F-GC (5-CGC-CCG-CCG-CGC-GCG-GCC-GGC-GGG-GCG-GGG-GCA-GGG-GAG-AGT-TTG-ATCCTG-GCT-CAG-3') and KPRUNS518. (5’ ATTACCGCGG'TGCTGG-3) (Maila et al., 2006; Surridge, 2007). $0.25 \mu$ of $5 \mu$ hot $20 \mathrm{mg} / \mathrm{ml}$ of bovin serum albumin and $27.75 \mu$ of sterile water. A reaction tube without template DNA was included as negative control.

The PCR programme was as follows; denaturing step at $95^{\circ} \mathrm{C}$ for $3 \mathrm{~min}$, followed by 33 cycles of 30 sec at $95^{\circ} \mathrm{C}$ for $30 \mathrm{sec}$ at $55^{\circ} \mathrm{C}$ and extension at $72^{\circ} \mathrm{C}$ for $1 \mathrm{~min}$, followed by a final extension at $72^{\circ} \mathrm{C}$ for $7 \mathrm{~min}$ and held at $4^{\circ} \mathrm{C}$. Amplified DNA was presented for sequencing.

\subsubsection{DNA Sequencing}

DNA sequencing was performed by next generation sequencing technique to determine the nucleotide sequence of isolates resistant to TBTCl using automated PCR cycle-genome sequence TM FLX systems from 454 Life Science TM and Roche Applied Science. Sequence analysis and alignment was performed using vecton NTI suite 9 (Infor Max, Inc) and the resulting nucleotide sequence were compared to sequence obtained from GenBank http://www.laheg.org/studies/webt.htm/) by BLAST Xanalysis using CLO BIO Software for every organisms [12].

\section{Results and Discussion}

The Onne Port is situated on the south coast of Nigeria where the crude oil of the country is deposited. This port is one of the busiest ports as it is involved in the shipping of crude oil and gas products and other cargoes. Sediment samples were analyzed for TBTCl resistant and degrading bacteria from various sampling sites of the port. Onne port was selected because of this high marine traffic and the shipping activities. The physiochemical characteristic of sediment from 5 sampling sites showed some variations, Total organic carbon (TOC) ranged from $2.18 \%$ to $1.22 \%$, Nitrate ranged from $0.69 \mathrm{mg} / \mathrm{kg}-0.42 \mathrm{mg} / \mathrm{kg}$, while total nitrogen ranged from $0.14 \mathrm{mg} / \mathrm{kg}$ $0.2 \mathrm{mg} / \mathrm{kg}$ respectively (Table 1 ). These values were seemingly low. These low values may be ascribed to the pollution caused by TBTCl. The presence of pollutant such as organotin has been reported to deplete the amount of nutrients available to organisms in the aquatic environment [13] [14]. Depletion of essential nutrient such as the result from this study has a range of effects on coastal ecosystems. It causes ecological changes that decrease the biological diversity in the ecosystem. On the other hand there was higher content of sulphate across the 5 sampling sites.

Table 1. Physicochemical properties of sediment from Onne Port.

\begin{tabular}{cccccc}
\hline Parameters & A & B & C & D & E \\
\hline TOC $(\%)$ & 2.18 & 1.1 & 1 & 3.5 & 1.22 \\
Nitrate $(\mathrm{mg} / \mathrm{kg})$ & 0.69 & 0.59 & 0.541 & 0.722 & 0.42 \\
Phosphate $(\mathrm{mg} / \mathrm{kg})$ & 0.016 & 0.013 & 0.023 & 0.018 & 0.01 \\
Sulphate $(\mathrm{mg} / \mathrm{kg})$ & 831.4 & 332.8 & 280.2 & 315.1 & 277.2 \\
Total nitrogen $(\mathrm{mg} / \mathrm{kg})$ & 0.14 & 0.17 & 0.23 & 0.18 & 0.2 \\
pH & 5.76 & 5.33 & 3.96 & 5.05 & 5.63 \\
E.C $(\mu \mathrm{s} / \mathrm{cm})$ & 4420.6 & 1877.3 & 1712.9 & 1775.1 & 1647.1 \\
\hline
\end{tabular}


The $\mathrm{pH}$ of the sediment was slightly high across the sampling points. Site A had a higher $\mathrm{pH}$ than the other sites (7.5). This may be attributed to the location of this site which was directly under the ships and also due to increase in the biological and chemical process that must have been induced by the organotin pollution. The $\mathrm{pH}$ of the aquatic environment determines the acidity and alkalinity of the system. The $\mathrm{pH}$ may be affected by the presence of organic acids, biological processes (Photosynthesis and respiration) and physical processes (turbulence and aeration) that can alter the concentration of dissolved carbon dioxide (Kiely, 1996). The pH is therefore critical to the activity of aquatic organisms because it influences the function of virtually all enzymes, hormones and protein which control all aspects of metabolism, growth and development. This results corroborates the report of other studies that the highest adsorption of TBTCl is observed between $\mathrm{pH} 6$ - 7 which reflects the areas of maximum overlap between the total negative surface charge and the concentration of TBT cation in solution [2] [15]-[18].

The enumeration of total bacterial counts is most crucial for estimating the TBTCl resistance and degradation in the habour.

The total bacterial counts varied from $42 \times 10^{2}$ to $64.4 \times 10^{2} \mathrm{cfu} / \mathrm{ml}$ when plated on MSA only. However, the viable counts on MSA to $3 \mathrm{mM}$, TBTCl and MSA + $5 \mathrm{mMTBTCl}$ ranged from $22 \times 10^{1}$ to $38.5 \times 10^{2} \mathrm{cfu} / \mathrm{ml}$ and $18 \times 10^{1}$ from $21.9 \times 10^{1} \mathrm{cfu} / \mathrm{ml}$ respectively, however the total viable count in MSA $+10 \mathrm{mM}$ TBTCl ranged from $1.1 \times 10^{1}-3.8 \times 10^{1} \mathrm{cfu} / \mathrm{ml}$ (Table 2). Statistically, total bacterial count varied significantly across the sample sites $\mathrm{p}<0.05$ (one way ANOVA). It was observed that for all sampled location with increasing concentrations of $\mathrm{TBTCl}$, the number of bacteria decreased significantly and the percentage of resistant bacterial was lower compared to the control.

The total viable count of sediment samples obtained from 5 sites in Onne Port indicates that approximately $65.6 \%$ of bacterial population is resistant to $3.0 \mathrm{mM}$ of TBTCl since these isolates could grow on MSA supplemented with TBTCl (Table 2). This report has shown that bacterial flora of sampling site A are more resistant then the other sites since this site was directly located under some ships. It is assumed that TBTCl was more concentrated in that site as a result of scrapping of paints from the ship or by direct leaching of paint containing TBTCl into the sediments. This report agrees with other finding that the antifoulants in ship paints, ship yards harbour is considered to be the prime source of TBT in the marine environment [19]-[21]. Most isolates failed to grow in the presence of higher concentration of TBTCl $(10 \mathrm{mM})$. Out of 97 isolates that showed resistance to $3.0 \mathrm{~mm}$ of TBTCl, only 2 isolates showed a consistent growth in presence of $5 \mathrm{mM}, 7 \mathrm{mM}$ and $10 \mathrm{mM}$ in TBTCl in MSA after $48 \mathrm{hr}$ incubation with the optimum condition for growth i.e. temperature at $30^{\circ} \mathrm{C}$ and $\mathrm{pH}$ 7.8 - 8.1. These two isolates were further studied based on their abilities to grow on concentration of $5 \mathrm{mM}, 7$ $\mathrm{mM}$ and $10 \mathrm{mM}$ of TBTCl. Most of the bacterial isolates could not grow in the presence of higher concentration of TBTCl (5 mM) due of cellular toxicity and inhibitory effect on metabolic processes and viability of bacterial strains [22] [23]. The 2 isolates that showed distinctive growth in the presence of high concentration of TBTCl $(10 \mathrm{mM})$ were identified to be Pseudomonas aeruginosa and Pseudomonas fluorescens. The morphological and biochemical properties of these strains were reported to use TBTCl as their main source of Carbon (Table 3).

Morphologically these are slightly curved rods, about 0.5 to $1.0 \mathrm{Nm}$ by 1.5 to $5.0 \mathrm{Nm}$ in length; they are motile and possess one or several polar flagella.

On the basis of biochemical and morphological characteristics of this isolates these strains were tentatively identified according to Bergey's Manual of Systematic Bacteriology as Pseudomonas aeruginosa and Pseudomonas fluorescence. They identity of these strains was confirmed by 16 SrRNA amplification by polymerase chain reaction (PCR). Their molecular identification is shown in Table 4.

The identity of the most potent strains was confirmed by 16 SrDNA gene amplification by polymerase chain reaction (PCR). The 16S rRNA sequence phylogenetic analysis using BLAST (Basic Local Alignment Search Tool) program [12] showed that the isolates were proteobacteria. The sequence was compared with other bacteria available in Gene bank (Altschul, 1990). The sequence was aligned with available 16 SrRNA reference sequences; similarities and alignment were obtained using BLAST [12] alogorithm to identify known sequence with a high degree of similarity. Two strains such as Pseudomonas fluorescens Jx and Pseudomonas aeruginosa On7 showed a high level of resistance to tributyltin at $10 \mathrm{mM}$. Although a few researchers has reported degradation of TBT by environmental microorganism up to $7 \mathrm{mM}$, isolation of TBT utilizing bacteria up to $10 \mathrm{mM}$ is limited [23].

This study clearly showed that some bacterial strains in Onne Port Nigeria are resistant to $10 \mathrm{mM}$ of TBTCl. Interestingly, one could easily conclude that these bacterial isolates are resistant to TBTCl probably utilizing it 
Table 2. Total viable counts of TBTCl resistant bacterial.

\begin{tabular}{cccccc}
\hline \multicolumn{5}{c}{ Vaible counts (cfu/ml) at varying TBTCL concentration } \\
\hline Sampling site & MSA only & MSA + 3 mM & MSA + 5 mM & MSA + 7 mM & MSN + 10 mM \\
\hline A & $64.4 \times 10^{2}$ & $34.3 \times 10^{2}$ & $20.2 \times 10^{1}$ & $10.3 \times 10^{1}$ & $3.8 \times 10^{1}$ \\
B & $61.2 \times 10^{2}$ & $38.5 \times 10^{2}$ & $21.4 \times 10^{1}$ & $9.2 \times 10^{1}$ & $2.1 \times 10^{1}$ \\
C & $60.3 \times 10^{2}$ & $28.7 \times 10^{1}$ & $21.9 \times 10^{1}$ & $8.9 \times 10^{1}$ & $1.2 \times 10^{1}$ \\
D & $42.1 \times 10^{2}$ & $22.8 \times 10^{1}$ & $18.1 \times 10^{1}$ & $7.8 \times 10^{1}$ & $1.1 \times 10^{1}$ \\
C & $58.3 \times 10^{2}$ & $24.6 \times 10^{1}$ & $19.5 \times 10^{1}$ & $5.4 \times 10^{1}$ & $1.3 \times 10^{1}$ \\
\hline
\end{tabular}

Keys: MSA: Mineral Salt Agar; TBTCL: Tributyltin Chloride.

Table 3. Biochemical properties of isolated bacterial strains.

\begin{tabular}{|c|c|c|c|c|}
\hline \multicolumn{5}{|c|}{ Test bacterial strains } \\
\hline & Pseudomonas & Aeruginosa & Pseudomonas & Fluorecens \\
\hline Grams reaction & - & & & - \\
\hline Citrate & + & & & + \\
\hline Indole & - & & & - \\
\hline MR & - & & & - \\
\hline VP & - & & & - \\
\hline Lactose & - & & & - \\
\hline Sucrose & - & & & - \\
\hline Glucose & - & & & - \\
\hline Urease & - & & & - \\
\hline TS I & - & & & - \\
\hline Catalase & + & & & + \\
\hline Oxidase & + & & & + \\
\hline Motility & + & & & + \\
\hline $\mathrm{H}_{2} \mathrm{~S}$ & - & & & - \\
\hline
\end{tabular}

Table 4. Molecular identification of isolates.

\begin{tabular}{cccc}
\hline Name of organism & Strain & \% similarity & Accession No. \\
\hline Pseudomonas fluorescens & $\mathrm{Jx}$ & 99 & GU 220720.1 \\
Pseudomonas aeruginosa & On 7 & 99 & Hq 377326.1 \\
\hline
\end{tabular}

as their source of carbon. Resistance of isolates may be due to the presence of TBTCl leached into the marine system due to heavy ship traffic since Onne Port is one of the largest and busiest ports in the country. It receives cargo vesssels at its various berths which dock for week during which TBT leaches to the marine environment due to hydrolysis as earlier reported by [24]. In addition to leaching of TBT, repairing and construction of ships involves processes such as blasting old paint which finally end up in the marine environment where TBT leaches gradually [24].

[25] findings have revealed that heavy contamination of coastal water by TBT was associated with major commercial harbours and ship repair activities involving removal of the old paint from the hull and application of a new coating which could release TBT as a waste discharge.

Microorganisms play significant role in the degradation of toxic pollutant such as organotin in the marine environment. Biotic processes have been demonstrated to be the most significant mechanism for degrading tributyltin both in soil as well as in fresh water, marine and estuarine environment [24]. Tributyltin is known to be present in three main compartment of the marine system: the surface microlayer, the water column, and at the surface layer of bottom sediments [26]. 
Our finding in this study Pseudomonas sp. being able to degrade tributyltin supports several studies [2] [4] [27].

These organisms continue to attract considerable interest for the remediation of both toxic organic pollutants and heavy metals. The ecotoxicological effects of organotins include morphological and productive reproductive aberrations and metabolic disruption in a variety of non-target organisms including shellfish and snails. They can be bioaccumulated in microorganisms which are at the base of the food web and from there into higher organism.

\section{Conclusion}

Microorganisms have been shown to bioremediate heavy metals and aromatic hydrocarbons of polluted sites but bioremediation of organotin contaminated sites is far away large-scale commercial process. Since there is scanty work on the mechanisms of the degradation of organotin, it is then important that isolates that can tolerate organotin to a large extent can be used in the cleanup of organotin contaminated site. Pseudomonas aeuroginosa and Pseudomonas fluorescens can be used for the bioremediation of contaminated site.

\section{References}

[1] Conney, J.J. and Wuertz, S. (1989) Toxic Effects of Tin Compounds on Microorganism. Indian Journal of Microbiology, 4, 375-402. http://dx.doi.org/10.1007/BF01569539

[2] Fent, K. (1996) Organotin Compound in Municipal Waste Water and Sewage Sludge: Contamination, Fate in Treatment Process and Ecotoxicological Consequences. Science and Total Environment, 185, 151-159. http://dx.doi.org/10.1016/0048-9697(95)05048-5

[3] Kannan, K. and Lee, R.F. (1996) Triphenyltin and Its Degradation Products in Foliage and Soils from Sprayed Pecan Orchards and Fish from Adjacent Ponds. Environmental Toxicological Chemistry, 15, 1492-1499. http://dx.doi.org/10.1002/etc.5620150910

[4] Gadd, G.M. (2000) Microbial Interaction with Tributyltin Compounds Detoxification, Accumulation and Environmental Fate. Science of the Total Environment, 258, 110-127. http://dx.doi.org/10.1016/S0048-9697(00)00512-X

[5] Fargasora, A. and Kizlink, J. (1996) Effect of Organotion Compounds on the Growth of Fresh Water Algae Scenedesmuquadricauda. Ecotoxicology of Environmental Safety, 34, 156-159. http://dx.doi.org/10.1006/eesa.1996.0057

[6] Kline, E.R., Jarvinen, A.W. and Knuth, M.L. (1989) Acute Toxicity of Triphenyltin Hydroxide to Three Cladoceran Species. Environmental Pollution, 56, 11-17. http://dx.doi.org/10.1016/0269-7491(89)90117-6

[7] Gadd, G.M. (1993) Microbial Formation and Transformation of Organomatallic and Organometaiioid Compounds. FEMS Microbial Reviews, 11, 297-316. http://dx.doi.org/10.1111/j.1574-6976.1993.tb00003.x

[8] Fukagawa, T.S., Konno, S.C., Takama, K. and Suzuki, S. (1994) Occurrence of Tributyltin (TBT) and Methimecury Tolerant Bacteria in Natural Seawater to Which TBT Was Added. Journal of Marine Biotechnology, 1, 211-214.

[9] Kawai, S., Kurokawa, Y., Harino, H. and Fukushima, M. (1998) Degradation of Tributyltin by a Bacterial Strain Isolated from Polluted Rivers Water. Environmental Pollution, 10, 259-263. http://dx.doi.org/10.1016/S0269-7491(98)00079-7

[10] Harino, H., Fukushima, M., Kurokawa, Y. and Kawai, S. (1997) Susceptibility of Bacteria Populations to Organotin Compounds and Microbial Degradation of Organotin Compounds in Environmential Waters. Environmental Pollution, 98, 157-162. http://dx.doi.org/10.1016/S0269-7491(97)00133-4

[11] APHA (1998) Standard Methods for the Examination of Water and Waste Water. 20th Edition, APHA-AWWA-WPCE, Washington DC.

[12] Altschul, S.F., Gish, W., Miller, W., Myers, E.W. and Lipman, D.J. (1990) Basic Local Alignment Search Tool. Journal of Molecular Biology, 215, 403-410. http://dx.doi.org/10.1016/S0022-2836(05)80360-2

[13] Udosen, E.D. (2007) Determination of Trace Metals and Fluxes in Sediments along a Segment of Qua Iboe River in Southern Nigeria. Journal of Natural and Applied Science, 2, 82-90.

[14] Atlas, R.M. (1981) Microbial Degradation of Petroleum: An Environmental Perspective. Microbiology Review, 45, 180-209.

[15] Weidenhaut, A., Arnold, C., Muller, S.R., Haderlien, S.B. and Schwarzenbach, R.P. (1997) Sorption of Organotin Biocides to Mineral Surfaces. Environmental Science and Technology, 31, 2603-2609. http://dx.doi.org/10.1021/es9700109

[16] Hoch, M. (2001) Organotin Compounds in the Environment—An Overview. Applied Geochemistry, 16, 719-743. 
http://dx.doi.org/10.1016/S0883-2927(00)00067-6

[17] Hoch, M. (2004) Assessment of Salinity Variations in TBT Adsorption onto Kaolinite and Montmorillonite at Different pH Levels. Water, Air and Soil Pollution, 152, 349-362. http://dx.doi.org/10.1023/B:WATE.0000015365.36939.dd

[18] Eggleton, J. and Thomas, K.V. (2004) A Review of Factors Affecting the Release and Bioavailability of Contaminants during Sediment Disturbance Events. Environmental International, 30, 973-980. http://dx.doi.org/10.1016/j.envint.2004.03.001

[19] Suyzuki, S., Fuagawa, T. and Takma, K. (1992) Occurrence of Tributyltin-Tolerant Bacteria in Tributlytin- or Cadmium-Containing Seawater. Applied Environmental Microbiology, 58, 3410-3412.

[20] Suzuki, S. and Fukagawa, T. (1995) Tributlyin Resistant Bacteria: A Summary of Recent Work. Journal of Industrial Microbiology, 14, 154-158. http://dx.doi.org/10.1007/BF01569897

[21] Wuertz, S., Miller, C.E., Pfister, R.M. and Conney, J.J. (1991) Tributyltin-Resistant Bacteria from Estuarine and Freshwater Sediments. Applied and Environmental Microbiology, 57, 2793-2789.

[22] Pettibone, G.W. and Cooney, J.J. (1986) Effect of Organotins on Fecal Pollution Indicator Organisms. Applied and Environmental Microbiology, 52, 562-566.

[23] Krishnamurthy, R., Gopinath, S.M., Dayananda, K.S and Dubey, S.K (2012) Isolation and Biological Characterization of Highly Potent Tributyltin Chloride Resistant Bacteria Alcaligenes sp. Swo (Strain Sd) from Marine Water of Goa, India. International Journal of Environmental Sciences, 2, 1742-1753.

[24] De Mora, S.J., Stewart, C. and Philips, D. (1995) Sources and Rate of Degradation of Tri(n-butyl)tin in Marine Sediments near Auckland, New Zealand. Marine Pollution Bulletin, 30, 50-57.

[25] Chau, Y.K., Maguire, R.J., Brown, M., Yang, F. and Batchelar, S.P. (1997) Occurrence of Organotin Compounds in the Canadian Aquatic Environment Five Years after the Regulation of Antifouling Uses of Tributyltin. Water Quality Research Journal of Canada, 32, 453-521.

[26] Barug, D. (1981) Microbial Degradation of Bis(Tributyltin) Oxide. Chemosphere, 10, 1145-1154. http://dx.doi.org/10.1016/0045-6535(81)90185-5

[27] Roy, U. and Bhosle, S. (2006) Microbial Transformation of Tributyltin Chloride by Pseudomonas aeruginosa Strain USS25 NCIM-5224. Applied Organometallic Chemistry, 20, 5-11. http://dx.doi.org/10.1002/aoc.997 